PRZEGLĄD RUSYCYSTYCZNY 2020, nr 4(172)

DOI $10.31261 / \mathrm{pr} .9103$

MICHAE BOHUN

Uniwersytet Jagielloński

(DORCID: https://orcid.org/oooo-00o2-8702-9441

\title{
REWOLUCYJNA KONTRREWOLUCJA DIALOGI KULTUR W MYŚLI ROSYJSKIEGO OŚWIECENIA
}

THE REVOLUTIONARY COUNTERREVOLUTION. THE CULTURAL DIALOGUES IN THE THOUGHT OF THE RUSSIAN ENLIGHTENMENT

One of the main features of the culture of the Enlightenment was universalism (cosmopolitanism) and secularization. In the presented article they were related to the problem of tension between revolution and counterrevolution in the thought of the Russian Enlightenment and in the activities of the authorities. The author points to three areas of intercultural dialogue between Western culture (Polish, German, French) and native Russian culture. They are shown as a tool to modernization and strengthen the Russian state, which bring unexpected revolutionary effects.

Keywords: Enlightenment in Russia, revolution, intercultural dialogue

Zadaniem poniższego tekstu jest ukazanie problemu, który wydaje się ważny dla kultury intelektualnej epoki Oświecenia, zwłaszcza zaś w krajach, uchodzących w tym okresie za peryferyjne, takich jak Polska czy Rosja. Zresztą do tej pory są one po części peryferyjne i nieufne wobec zachodniej nowoczesności, co doskonale widać w zwątpieniu we własną europejską tożsamość i w nieumiejętności sprostania wyzwaniom współczesnego świata. Pytanie, jakie chciałbym postawić, sformułować można następująco: czy modernizacyjny wysiłek, charakterystyczny dla epoki Oświecenia, był procesem rewolucyjnym? A może przeciwnie: miał powstrzymać rewolucyjne załamanie cywilizacyjne za pomocą czegoś, co w socjologii nazywa się ideologią kontroli modernizacji? Pozytywna odpowiedź na drugie pytanie prowadzi do wniosku, że dla kultury rosyjskiej Oświecenie było rewolucją, ale o kontrrewolucyjnych intencjach i ewidentnie kontrrewolucyjnych rezultatach. Z drugiej jednak strony kontrrewolucyjne 
zamiary i działania wzmogły desydenckie i emancypujące ideały i dążenia najpierw elit, potem szerszych kręgów rosyjskiego społeczeństwa.

W najbardziej ogólnym ujęciu mamy tutaj do czynienia z głęboką, odgórnie kontrolowaną zmianą, która prowadzić miała do unowocześnienia państwa i wzmocnienia politycznego, przy minimalnym naruszeniu struktury społecznej i autorytarnego sposobu sprawowania rządów. W znacznej mierze instrumentem tej kontroli były rozmaite relacje międzykulturowe (dialogi kultur), inspirowane i sterowane przez najwyższe kręgi władzy. Trzeba zatem zwrócić uwagę na pojawiające się $\mathrm{w}$ tej epoce spotkania i relacje pomiędzy kulturą lokalną (tradycyjną) a kulturami obcymi, będącymi rezerwuarem wartości i strategii modernizacyjnych. Zjawisko to ma też wymiar wewnętrzny w formie niewolnego od spięć i konfliktów dialogu pomiędzy dawną kulturą religijną (Święta Ruś) a nową kulturą świecką (Imperium). I to jest być może główne napięcie charakterystyczne dla Oświecenia rosyjskiego. Warto jednak podkreślić, że okazuje się ono zjawiskiem uniwersalnym, ujawniającym się na przykład w formie rozdarcia pomiędzy Oświeceniem „radykalnym” a „umiarkowanym” (wg określeń Jonathana Israela ${ }^{1}$ ), albo Oświeceniem sekularnym a Oświeceniem chrześcijańskim (co dość dobrze widać było między innymi na ziemiach dawnej Rzeczypospolitej).

Napięcie pomiędzy rewolucją a kontrrewolucją jest zatem istotne. Poniżej przedstawię raczej hipotezy i pytania dotyczące tego zagadnienia, nie zaś rozstrzygnięcia i pogłębione interpretacje. Wierzę jednak, że mogą one być przydatne w nowym problematyzowaniu tej zapomnianej i niedocenianej epoki. Wypada zacząc od kwestii najbardziej ogólnych i dobrze znanych, ale niezmiernie ważnych. Wraz z Oświeceniem utrwala się w Rosji mechanizm zmiany społecznej i politycznej, który nazwać można „rewolucją od góry” albo „rewolucją od tronu”. Oświeceniowa rewolucja rozpoczyna się od dramatycznej konstatacji (będącej wynikiem konfliktów zbrojnych z przełomu XVII i XVIII wieku), że zasoby społeczne i gospodarcze, którymi

1 Na temat nowej fazy dyskusji nad Oświeceniem radykalnym, zob. np. J. Israel, „Radykalne Oświecenie” - peryferia, centrum czy główne oblicze Oświecenia za oceanem (1650-1850)?, przeł. A. Tomaszewska; M.C. Jacob, Jak bardzo radykalne było Oświecenie i co oznacza „radykalne”?, przeł. A. Tomaszewska. Oba teksty zamieszczone w tomie J. Miklaszewska, A. Tomaszewska (red.), Filozofia Oświecenia. Radykalizm - religia - kosmopolityzm, Wydawnictwo Uniwersytetu Jagiellońskiego, Kraków 2015, s. 17-64. 
dysponuje państwo moskiewskie, są zbyt słabe, aby dotrzymać kroku modernizującej się Europie. Na to wyzwanie próbował odpowiedzieć Piotr I wraz z otaczającym go kręgiem szczególnego rodzaju dworskich intelektualistów („uczona drużyna”). Oczywiście wyzwanie to miało pierwotnie charakter militarny i czysto techniczny, ale stopniowo rozszerzało się inne sfery życia. Próba importu samych tylko osiągnięć technologicznych i procedur gospodarczych bez ich kontekstu kulturowego, ściślej: bez wiedzy naukowej i kultury intelektualnej, okazała się mało skuteczna i kosztowna. Był to bezpośredni impuls do powstania szczególnej grupy ludzi, których zadaniem było przyswojenie sobie zachodniej kultury i rozpowszechnienie jej w warstwach wyższych ówczesnego społeczeństwa. Tak narodziła się inteligencja, która została powołana do życia przez Piotra I pierwotnie jako zespół kogoś w rodzaju intelektualnych technokratów czy może „technologów modernizacji” ${ }^{2}$. W ciągu stulecia grupa ta przekształciła się w warstwę społeczną, by potem stać się nosicielką świadomości rewolucyjnej i głównym oponentem dla carskiego reżimu. Inteligencja miała służyć wzmocnieniu państwa, ale już od połowy XVIII wieku zaczęła domagać się wolności osobistej i praw politycznych. I to nie tylko dla siebie, nie tylko dla warstwy szlacheckiej, z której się wywodziła, ale dla całego społeczeństwa, łącznie z chłopstwem, czyli faktycznymi niewolnikami. Taki oświeceniowy duch krytyki społecznej i wolnościowe ideały przenikały na przykład publicystykę Nikołaja Nowikowa (1744-1818), budując moralistyczny patos rosyjskiej inteligencji, aby następnie ulec wzmocnieniu i politycznemu doprecyzowaniu w osobie i dziele Aleksandra Radiszczewa (1749-1802). Kulminacją tego procesu $\mathrm{w}$ ramach kultury Oświecenia byli oczywiście dekabryści - stojący już jakby na granicy epok i tragicznie wieńczący rosyjski Wiek Świateł. W moim przekonaniu znaczenie tego ruchu wyraża się przede wszystkim w próbie urzeczywistnienia emancypujących i egalitarnych ideałów radykalnego Oświecenia poprzez akcję zbrojną. To był końcowy, dramatyczny akord epoki: namiastka rewolucji, która dążąc do przemiany, zakończyła się klęską szlacheckich inteligentów.

Warto zwrócić uwagę na jeszcze jedną kwestię. Zainicjowana i forsowana przez Piotra I europeizacja, chociaż niepozbawiona przemo-

${ }_{2}$ Na temat związków pomiędzy Piotrem I a inteligencją zob. M. Bohun, Inteligencja. Rosyjskie przestrogi i polskie nadzieje, w: J. Dobieszewski, J. Skoczyński, M. Bohun (red.), Wokót Andrzeja Walickiego. Almanach myśli rosyjskiej, Uniwersytet Warszawski. Wydział Filozofii i Socjologii, Warszawa 2009, s. 145-146. 
cy, nie była wstrząsem ani dla Rosji, ani dla Zachodu. Wynikało to, po pierwsze, ze swoistości kulturalnej tamtej epoki: Oświecenie ma charakter uniwersalistyczny, jest jednolitą konstelacją kulturalną, która na kontynencie sięgała od Lizbony po Petersburg. Rosja w świadomości jej elit była częścią Europy, która - zgodnie z ówczesnym powiedzeniem - sięga wszędzie tam, gdzie rozmawia się po francusku. W przypadku Rosji jeszcze ważniejsze wydają się fakty, na które zwrócił uwagę Martin Malia. Po pierwsze, Oświecenie ma charakter sekularny - związane jest z procesem laicyzacji kultury i polityki, co wyraźnie osłabiało niszczycielską moc antagonizmów religijnych. Świetnie widać to na przykładzie sceptyczno-ironicznego stosunku Piotra I do prawosławia. To samo dotyczy zgromadzonych wokół niego intelektualistów, w tym duchownych, z Teofanem Prokopowiczem (1681-1736) na czele. Po drugie, forma polityczna jaką narzucił Rosji car-reformator (a może jednak rewolucjonista?), czyli unowocześniony absolutyzm, nie różnił się tak bardzo ani od zachodniego wzorca „dobrze urządzonego państwa policyjnego”, ani od tradycyjnego modelu „powszechnego państwa służebnego carstwa moskiewskiego”. Nowa, zeświecczona Rosja imperialna stała się państwem w stylu europejskim - monarchią militarną ${ }^{3}$. A zatem przyłączenie Rosji do Europy nie było rewolucją sensu stricto, aczkolwiek miało rewolucyjne konsekwencje i zapoczątkowało dwustuletni okres permanentnej rewolucji. Tego ostatniego określenia używam w sensie, jaki nadał mu twórca tego terminu Pierre Proudhon, abstrahując od tego znaczenia, jakie przypisał do niego później i spopularyzował Lew Trocki.

Czynnikiem w decydujący sposób określającym charakter rosyjskiego Oświecenia był charakterystyczny dla tej epoki uniwersalizm czy też wręcz kosmopolityzm, dzięki któremu można mówić o europejskiej jedności, wspólnocie kulturalnej ponad granicami państwowymi i językowymi, do której przyłączyła się Rosja. Ten cywilizacyjny akces miał przede wszystkim aspekt intelektualny, filozoficzno-ideologiczny, który wszakże pociągał za sobą polityczne reperkusje. Chciałbym w tym miejscu przywołać wyjątek ze słynnej niegdyś, a dziś zapo-

3 Por. M. Malia, Sowiecka tragedia. Historia komunistycznego imperium rosyjskiego 1917-1991, przeł. M. Hułas, E. Wyzner, Philip Wilson, Warszawa 1998, s. 75 . 
mnianej, książki Carla Beckera, który znakomicie oddaje uniwersalistycznego ducha oświeceniowej ideologii:

Imperium filozofów było wielonarodowym kondominium, dla którego Francja była zaledwie krajem macierzystym, a Paryż tylko stolicą. Gdziekolwiek się wówczas pojedzie [...], wszędzie spotka się ich: filozofów, którzy posługują się tym samym językiem, i których przekonania stworzył ten sam klimat opinii [...]. Są ludźmi wszystkich krajów i równocześnie żadnego. Są obywatelami świata, ludźmi wyzwolonymi, którym wydaje się, że im pierwszym dane jest patrzeć na skąpany teraz w potokach światła kosmos; kosmos, w którym wszystko to, co warte uwagi, jest widzialne, a wszystko to, co widzialne, w ostatecznej konsekwencji zawsze okazuje się cudownie jasne, proste i zrozumiałe dla ludzkiego umysłu - w każdym razie dla umysłów filozofów ${ }^{4}$.

Rosyjska rewolucja rozpoczęta w XVIII wieku żywi się taką właśnie ideologią (filozofią): racjonalistyczną, uniwersalistyczną, wolnomyślicielską, wolnościową. Jej celem jest wyzwolenie jednostki i społeczeństwa z zależności feudalnych i ze stanu „niedojrzałości”, który wymaga patrymonialnej opieki monarchów i kapłanów. Już w połowie XVIII wieku rosyjscy koryfeusze Wieku Światel, na czele z Michałem Łomonosowem (1711-1765), byli przekonani, że przeznaczeniem Rosji jest nie tyle recepcja, ile rozpowszechnianie ideałów Oświecenia, tak aby narodziła się globalna kultura ogólnoludzka oparta na ujednoliconych prawach i zasadach ${ }^{5}$. Jednocześnie miał to być akt emancypacji, w którym rozumne jednostki uwalniały się od brzemienia tradycji religijnej, instytucji kościelnych i dawnej tyranii politycznej. Rozum jako fundament ładu wyzwalał człowieka od opieki uświęconych niegdyś instancji, od pełnej przesądów wiary i niewolniczej moralności. W gruncie rzeczy to samo miał na myśli Immanuel Kant, próbując odpowiedzieć na pytanie „czym jest Oświecenie".

W całej Europie daje się zauważyć w tym czasie ten sam proces, w którym stare instytucje, tradycje i przesądy, dyskurs religijny i bezwarunkowe podporządkowanie dynastycznym władcom zastępowane są przez to, co „rozumne” i „naturalne”, a więc wspólne wszystkim ludziom i wyzwalające. Warto w tym kontekście przywołać słowa Aleksandra Hercena:

4 C. L. Becker, Państwo Boże osiemnastowiecznych filozofów, przeł. J. Ruszkowski, Zysk i S-ka, Warszawa 2008, s. 46.

5 Zob. Н.Ф. Уткина, А.Д. Сухов (red.), Русская мысль в век Просвещения, Наука, Москва 1991, s. 155. Jeszcze wcześniej z teorią „oświecenia powszechnoświatowego" wystąpił Wasyl Tatiszczew (1686-1750). 
Cała nasza edukacja prywatna i publiczna ma charakter zdecydowanie uniwersalny. Żadna edukacja nie jest mniej religijna niż nasza i bardziej wielojęzyczna, szczególnie jeśli idzie o języki nowożytne. To reforma Piotra I, wybitnie realistyczna, laicka i mająca charakter ogólnoeuropejski, nadała ten charakter wychowaniu u nas [...]. Wychowanie odrywa u nas młodzież od niemoralnej gleby, humanizuje ją, cywilizuje i przeciwstawia Rosji oficjalnej ${ }^{6}$.

Jest to kolejny istotny rys Oświecenia: nacisk na oświatę; przekonanie, że uwolniona od religijnej kostyczności edukacja może stworzyć nie tylko nowe warstwy społeczne gotowe do modernizacji kraju, ale nową klasę czy nawet - co doskonale widać w mitologii Rewolucji Francuskiej - nowego człowieka. Znakomicie wychwycił to Jerzy Plechanow, który analizując wpływ francuskiej filozofii Oświecenia, głównie Helwecjusza, na rosyjskich reformatorów szkolnictwa, pisał o ich wizji edukacji mającej stworzyć „nową rasę ludzi”

III

Uniwersalistyczny duch Oświecenia w przypadku Rosji został wzmocniony przez otwartość jej nowożytnej kultury na obce wpływy. Kosmopolityzm można uznać za jeden z owoców oświeceniowej rewolucji, która w Rosji rozpoczęła się - przynajmniej taka jest moja hipoteza - od dialogu z kulturą polską. Znamienne jest jednak to, że dialog ten nawiązany $\mathrm{w}$ siedemnastym stuleciu miał pierwotnie charakter czysto religijny (teologiczny) i był zapośredniczony przez Ukrainę, ale ostatecznie doprowadził do ukształtowania się świeckiego modelu rosyjskiej kultury, podporządkowującej sobie małoruskie kresy. Przede wszystkim trzeba zwrócić uwagę, że rozwój myśli prawosławnej, instytucjonalnie wyrażający się między innymi w założeniu w Kijowie Akademii Mohylańskiej, był wynikiem związków politycznych ziem ukraińskich z Rzeczpospolitą Obojga Narodów. Warto podkreślić dwa zjawiska. Pierwsze to specyficznie instytucjonalny aspekt Oświecenia wyrażający się w znaczeniu, jakie przypisywano w tej epoce zakładaniu i prowadzeniu instytucji naukowych i kulturalnych. Szkoły, uczelnie, akademie, muzea, teatry... ucieleśniały oświeceniową ideologię. Drugi aspekt jest nieco bardziej subtelny. Wasyl Zieńkowski pisze

6 A. Hercen, Pisma filozoficzne, t. II, przeł. W. Bieńkowska, PWN, Warszawa 1966, s. 276-277.

7 Zob. J. Plechanow, Historia rosyjskiej myśli społecznej, t. I, przeł. R. Hekkier i in., Książka i Wiedza, Warszawa 1966, s. 364. 
w tym kontekście o „cerkiewnym odrodzeniu” na Ukrainie, które następnie promieniowało na Północ, zwłaszcza po przyłączeniu ziem ukraińskich do Rosji w połowie XVII stulecia. W 1685 roku w Moskwie powstaje uczelnia „grecko-słowiańska” (wzorowana na akademii działającej w Kijowie), przemianowana w 1700 roku na Akademię Słowiańsko-Łacińską. To był nie tylko ważny impuls intelektualny, ale też okcydentalizacja myślenia: uczoność południowo-ruska była niemal zupełnie zależna od kultury zachodniej, ale pomimo tego oddalania się od wschodnich korzeni chrześcijaństwa, generalnie wniosła pozytywny wkład w życie umysłowe Rosji ${ }^{8}$. Akademie spełniały rolę ośrodków dialogu kultur zarówno narodowych (polskiej, niemieckiej, greckiej, ruskiej), jak i intelektualnych (świeckiej-naukowej i religijnej-teologicznej). Trzeba też dodać, że w obu tych akademiach filozofię wykładano po łacinie - łacina była uniwersalnym językiem wiedzy świeckiej w odróżnieniu od hebrajskiego, greckiego i starocerkiewnego - języków wiedzy świętej.

Jednak w odróżnieniu od Ukrainy w Moskwie zainteresowanie Zachodem rozwijało się poza sferą kościelną, a nawet przy pewnym oporze duchowieństwa. Za panowania Piotra I stało się jasne, że okcydentalizacja jest mniej lub bardziej wymuszoną sekularyzacją. Warto też dodać, że chociaż car znał język polski (przynajmniej w stopniu biernym), to za jego panowania zmienia się główny podmiot dialogu kultur - teraz kultura niemiecka staje się modernizacyjną dominantą i to we wszystkich sferach życia. Wśród ideologów-intelektualistów z kręgu otaczającego cara („uczona drużyna” Piotra) na wyróżnienie zasługuje bez wątpienia Prokopowicz jako promotor nowoczesnej wersji teorii oświeconego absolutyzmu (w której widać pogłos zarówno teorii prawa natury, jak i umowy społecznej). Prokopowicz - choć sam był wysokim hierarchą Cerkwi - broni priorytetu zasady świeckiej, nauki i rozumu, które przedkłada ponad wiarę religijną. Praktycznym efektem tego stanowiska było faktyczne podporządkowanie Cerkwi państwu w wyniku reform kościelnych oraz przejęcie przez państwo sporej części majątków cerkiewnych.

Wyrazistym symbolem niemiecko-rosyjskiego dialogu czasów Piotra I jest postać jednego z największych filozofów Oświecenia, a pewnie i filozofii w ogóle, czyli Gotfryda Leibniza. Jego związki z Rosją są różnorakie. Warto przynajmniej przywołać jego koncepcję dziejowego „kołowrotu”, zgodnie z którą, za panowania Piotra I palma pierwszeń-

8 В.В. Зеньковский, История русской философии, т. I, ч. 1, Эго, Ленинград 1991, s. 56-57. 
stwa kulturalnego przechodzi w ręce Rosji - nowego narodu, który może wykorzystać i zjednoczyć osiągnięcia Europy i Azji. W pewnym sensie koncepcja ta stanowi ogniwo pośrednie pomiędzy eschatologicznym konceptem Moskwy Trzeciego Rzymu mnicha Filoteusza a nowożytnymi wersjami rosyjskiego i sowieckiego mesjanizmu (misjonizmu). W moim przekonaniu ważniejsze jest jednak to, że autor Monadologii przygotowywał konkretne rozwiązania, wśród których warto przypomnieć projekt ustanowienia carskiej Akademii Nauk czy całościowy plan przebudowy aparatu państwowego, mający usprawnić procesy reformowania i zarządzania w Rosji. W jego wizji rosyjskie państwo idealne to maszyna, w której pracuje układ dziewięciu, zazębiających się „kolegiów” (resortów). Trzeba przyznać, że w tym projekcie najpełniej wcielało się przekonanie wielu ludzi Oświecenia, że instytucje państwowe i życie społeczne mogą być świadomie i całościowo przebudowane na podstawie zasad racjonalnych i naukowych, które są w stanie zastąpić starodawne instytucje i obyczaje ${ }^{9}$. W pełni wyraża się tutaj oświeceniowa skłonność do rozumnego urządzania państwa i doskonalenia społeczeństwa za pomocą reform prawnych i rozpowszechniania edukacji. To przekonanie dochodzi w pełni do głosu w połowie XVIII stulecia w pierwszej fazie rządów Katarzyny II. Dokonuje się wtedy kolejna przemiana podmiotów dialogu kultur.

Po Polsce i Niemczech palmę pierwszeństwa przejmuje Francja - centrum oświeceniowej kultury - co wyraźnie zmienia nie tylko zewnętrzny obraz Rosji, ale i jej ideologię. Wypada w tym miejscu przywołać słowa Andrzeja Walickiego:

W czasach Katarzyny II rosyjskie życie intelektualne uległo jednak przemożnemu wpływowi oświeceniowej filozofii francuskiej. Wpływom francuskim sprzyjała początkowo sama cesarzowa. Więcej nawet - usiłowała ona uczynić z francuskiej myśli oświeceniowej narzędzie własnej polityki wewnętrznej i zewnętrznej. Próbowała rozbudzić w Rosji ruch umysłowy, którym mogłaby odgórnie kierować, zachowując dla siebie prawo inicjatywy. $Z$ tego powodu nazywano Katarzynę „filozofem na tronie”. Określenie to jest z pewnością zbyt zaszczytne. Ale mimo to nie sposób pominąć Katarzyny w wykładzie dziejów filozofii rosyjskiej ${ }^{10}$.

Powszechnie znane są kontakty carycy z wybitnymi przedstawicielami Oświecenia: Wolterem, Denisem Diderot, Helwecjuszem.

9 Zob. Русская мысль..., s. 72; о wpływie Leibniza na Łomonsowa zob. В. В. Зеньковский, История..., s. 104.

${ }^{10}$ A. Walicki, Zarys myśli rosyjskiej. Od Oświecenia do renesansu religijno-filozoficznego, Wydawnictwo Uniwersytetu Jagiellońskiego, Kraków 2005, s. 37-38. 
W pierwszej fazie panowania kontakty z nimi i ich idee stanowią ideologiczny fundament sprawowanej przez nią władzy. Nawet jeśli ten fundament ograniczał się do sfery czysto werbalnej, to i tak wywarł rewolucyjny wpływ na rzeczywistość wschodnio-północnej monarchii. Najdobitniej i najkrócej ujął to Plechanow: wolnościowe idee Oświecenia oczyściły rosyjskie samowładztwo z elementów azjatyckiej tyraniii ${ }^{11}$.

W takiej perspektywie doskonale widać dialektykę rewolucji i kontrrewolucji Oświecenia, charakterystyczną zresztą nie tylko dla Rosji. Z jednej strony przejawia się tutaj nieco naiwna wiara filozofów w roztropną monarchię absolutną czy raczej, znowu wedle celnego dictum Plechanowa, w monarchę tak oświeconego, że zechce użyć swej despotycznej władzy dla unicestwienia despotyzmu. Nadzieje takie wiązano w tym czasie nie tylko z „Semiramidą Północy”, jak nazwał carycę Wolter. Z drugiej strony trzeba zwrócić uwagę na instrumentalne traktowanie filozofów i odmienność ich sposobu myślenia od współczesnych im władców o absolutystycznych skłonnościach. Monarchowie przychylnie patrzyli na oświeceniową filozofię jako na narzędzie umocnienia ich własnej władzy, sprzyjające likwidacji dawnych instytucji, tradycji i obyczajów, które mogłyby ograniczać ich rządy. Filozoficzna walka z przeżytkami średniowiecza i feudalizmu miała pomóc w konsolidacji władzy i poszerzeniu jej zakresu ${ }^{12}$.

Katarzyna II mówiła o Wolterze „mój nauczyciel”, otaczała opieką autorów Encyklopedii, zapraszała koryfeuszy Oświecenia na swój dwór. Nie można wykluczyć, że jednym ze źródeł tej przyjaźni i protekcji względem francuskich philosophies mogły być napięte stosunki z królem Francji na tle nieporozumień związanych z rozbiorem Polski i kwestią turecką ${ }^{13}$. Utrzymując kontakty z filozoficznymi „buntownikami" czyniła przytyk Wersalowi. Oczywiście sytuacja uległa diametralnej zmianie pod koniec lat 8o., po okresie wojen chłopskich w Rosji, a zwłaszcza po wybuchu Rewolucji Francuskiej. Cesarzowa kazała usunąć popiersie Woltera z pałacowych pokoi, a przede wszystkim nakazała wycofanie jego dzieł (jak też wielu innych nieprawomyślnych książek) ze składów księgarskich. Jeszcze bardziej drastyczna zmiana dotknęła rosyjskich luminarzy Oświecenia. Na początku panowania caryca względnie łagodnie odnosiła się do różnych przejawów krytyki społecznej i propagowania ideałów humanitarnych, a nawet wolno-

${ }^{11}$ J. Plechanow, Historia..., s. 341.

${ }_{12}$ Tamże, s. 322-323, 437.

${ }^{13}$ Zob. Русская мысль..., s. 202. 
ściowych, ale potem na głównych przedstawicieli oświeceniowego „radykalizmu” posypały się kary (włącznie wyrokiem śmierci dla Radiszczewa, zamienionym na zesłanie oraz uwięzieniem bez sądu Nowikowa). Panowanie Katarzyny II to doskonała ilustracja dialektyki rewolucji i kontrrewolucji w rosyjskim Oświeceniu. James Billington pisze:

Niewielu innych władców w jej epoce snuło równie rozległe plany reform i stało się obiektem równie entuzjastycznych komplementów ze strony philosophies, lecz niewielu osiągnęło tak mało na płaszczyźnie praktycznej ${ }^{14}$.

W przygotowanej z rozkazu carycy i powszechnie jej przypisywanej Instrukcji legislacyjnej znakomicie widać tę dialektykę rewolucji i kontrrewolucji. Sama zaś Instrukcja jest świetnym przykładem powszechnej w epoce Oświecenia tendencji do racjonalnego projektowania życia społecznego, planowania reform, wiary w racjonalne prawo kreujące nowy porządek świata i nowego człowieka. Motyw ten jest równie czytelny w „katarzyńskiej” Instrukcji, jak i w działalności Michała Spierańskiego (1772-1839) - głównego ideologa reform z początku panowania Aleksandra I. Idee i losy Spierańskiego mogą być traktowane tak samo jak idee i losy dekabrystów, czyli jako dramatyczne zamknięcie Wieku Świateł w Rosji. Same jednak plany przekształceń, choć nie zrealizowane, stanowią ważny czynnik nie tylko rosyjskiego Oświecenia. Te projekty są wyrazem zmiany statusu i samowiedzy jednostek, które mogą tworzyć wizje przemian, potwierdzając tym samym swoją godność, która oparta jest nie na pochodzeniu czy kastowej przynależności, lecz na osobistym talencie, rozumie, zasługach ${ }^{15}$. Była to tendencja powszechna w całej Europie. Becker w tym kontekście pisze:

Głównym przedmiotem zainteresowania osiemnastowiecznych filozofów było nie tyle stabilizowanie społeczeństwa, ile jego zmiana. Oni nie pytali, w jaki sposób społeczeństwo stało się tym, czym jest, ale w jaki sposób można uczynić je lepszym niż jest ${ }^{16}$.

Droga, jaką przebyła Katarzyna II, jest szczególna, ale nie wyjątkowa: od przyjaźni z filozofami, od planów reformy państwa utrzymanych w duchu idei Monteskiusza, Beccari i Diderota... do ostrej

${ }^{14}$ J.H. Billington, Ikona i topór. Historia kultury rosyjskiej, przeł. J. Hunia, Wydawnictwo Uniwersytetu Jagiellońskiego, Kraków 2008, s. 200.

${ }^{15}$ Русская мысль..., s. 72.

${ }^{16}$ C. L. Becker, Państwo..., s. 102, por. s. 51, 92. 
cenzury, prześladowania myślicieli i moralistów, konfiskowania książek i zamknięcia Rosji przed europejskimi wpływami. Nader podobny szlak przeszedł jej ukochany wnuk Aleksander I, którego panowanie zamyka okres Oświecenia w Rosji. On także zaczął od liberalnych projektów i planów, których namacalnym efektem była nowoczesna konstytucja Królestwa Polskiego, by skończyć na religijnej egzaltacji, krępowaniu i represjonowaniu szkolnictwa wyższego czy wprost tyranii sprawowanej rękami Aleksego Arakczejewa. Historia zatoczyła kontrrewolucyjne koło. Zdesakralizowane przez Piotra I państwo za panowania Aleksandra na powrót staje się mistyczną despotią, uznając siebie za święte i sakralne ${ }^{17}$.

\section{IV}

Dialog pomiędzy tradycyjną kulturą religijną a nowoczesną kulturą świecką - to być może najważniejszy aspekt rosyjskiego Oświecenia. Jako taki warty jest oddzielnego, szczegółowego omówienia. Ja skupię się na ogólnej konstatacji, która może służyć jako podsumowanie powyższych wywodów.

Oświecenie jest przede wszystkim epoką sekularyzacji, kiedy pojawia się samodzielna kultura świecka, która wchodzi w ostry spór $\mathrm{z}$ dominującą dotąd świadomością religijną. Ale w Rosji przełom dokonuje się także w samej Cerkwi, która po reformach Piotra I, porzuca marzenie o świętej misji teokratycznego państwa a nawet próbuje - z różnymi efektami - wyzwolić się z politycznej zależności wobec caratu. Jest to, jak uważa Zieńkowski, wydarzenie najwyższej wagi - ostateczne i pełne zeświecczenie władzy państwowej i narodziny nowoczesnej świadomości narodowej, w której „Święta Ruś” staje się figurą retoryczną, a wyznacznikiem wyobraźni politycznej staje się idea „Wielkiej Rosji” ${ }^{18}$. Ale poczynić trzeba jedno zastrzeżenie. W rosyjskim Oświeceniu (inaczej niż w europejskim) antyklerykalizm, ani tym bardziej ateizm, nie stanowiły dominant w procesie społecznej i kulturowej rewolucji. Rosyjscy reprezentanci Wieku Świateł nie musieli tracić czasu i sił, żeby dowodzić konieczności ograniczenia wpływów religii i instytucjonalnej Cerkwi. Zrobili to za nich bowiem władcy - i to nie w teorii, ale w praktyce - znacząco obniżając suwerenność i autorytet duchowieństwa, poddając instytucje cerkiewne

17 Г. В. Флоровский, Пути русского богословия, [s.n.], Париж 1937, s. 133.

${ }^{18}$ В. В. Зеньковский, История..., s. 55, 60. 
świeckiemu zarządowi państwa. Można powiedzieć, że antyreligijną rewolucję przeprowadzili za filozofów monarchowie (zwłaszcza Piotr I i Katarzyna II) w imię poszerzenia i pogłębienia swojej władzy. Prokopowicz, wykorzystując idee nowożytnej filozofii, stworzył jedynie ideologiczne uzasadnienie dla laicyzujących posunięć władzy.

Generalnie uznać należy, że orientacja religijna została zastąpiona przez orientację społeczną - i jest to motyw dość charakterystyczny dla całego Oświecenia. Myśl oświeceniowa nastawiona była przede wszystkim na zagadnienia reformy i melioracji ludzkiego życia na ziemi, doskonalenia instytucji, poszerzania wiedzy o świecie, które stanowić miały punkt wyjścia dla rozwoju moralności. Jest to trwały motyw emancypacji człowieka jako istoty racjonalnej od władzy bóstw, mitów i przestarzałych instytucji. Źródłem wolności powinien być rozum, który urzeczywistniać się może w krytycznie i badawczo nastawionych do świata jednostkach, jak też w racjonalnie skonstruowanych instytucjach oświeconej monarchii absolutnej.

Rosyjskie Oświecenie znakomicie ukazuje dialektyczne napięcie charakterystyczne dla tej epoki w większości ówczesnych krajów. Rewolucja rosyjska nie była tak spektakularna, jak wielkie rewolucje tego czasu: angielska, amerykańska i francuska, ale cechowała się tą samą tendencją i marzeniem o stworzeniu nowego człowieka, nowego społeczeństwa i nowego świata na ruinach przestarzałych i opresyjnych instytucji feudalnych i religijnych. Jednak ze względu na faktu, że ta modernizująca rewolucja była w Rosji inspirowana i prowadzona odgórnie (rewolucja od tronu), jej rezultaty miały często kontrrewolucyjne reperkusje, łagodzone jednak przez dialogi różnych kultur dokonujący się w jej ramach.

\section{REFERENCES}

Becker, Carl Lotus. Państwo Boże osiemnastowiecznych filozofów. Transl. Ruszkowski, Janusz. Warszawa: Zysk i S-ka, 2008.

Billington, James H. Ikona i topór. Historia kultury rosyjskiej. Transl. Hunia, Justyn. Kraków: Wydawnictwo Uniwersytetu Jagiellońskiego, 2008.

Bohun, Michał. "Inteligencja. Rosyjskie przestrogi i polskie nadzieje.” Wokót Andrzeja Walickiego. Almanach myśli rosyjskiej. (Eds.) Dobieszewski, Janusz. Skoczyński, Jan. Bohun, Michał. Warszawa: Uniwersytet Warszawski. Wydział Filozofii i Socjologii, 2009. 


\section{MICHAŁ BOHUN}

Florovskiy, Georgiy Vasilievich. Puti russkogo bogosloviya. Parizh: [s.n.], 1937 [Флоровский, Георгий Васильевич. Пути русского богословия. Париж: [s.n.], 1937].

Hercen, Aleksander. "O rozwoju idei rewolucyjnych w Rosji." Hercen, Aleksander. Pisma filozoficzne. T. II. Transl. Bieńkowska, Wiera. Warszawa: Książka i Wiedza, 1966.

Israel, Jonathan. "'Radykalne Oświecenie’ - peryferia, centrum czy główne oblicze Oświecenia za oceanem (1650-1850)?”. Filozofia Oświecenia. Radykalizm - religia - kosmopolityzm. (Eds.) Miklaszewska, Justyna. Tomaszewska, Anna. Transl. Tomaszewska, Anna. Kraków: Wydawnictwo Uniwersytetu Jagiellońskiego, 2015. 17-46.

Jacob, Margaret C. "Jak bardzo radykalne było Oświecenie i co oznacza 'radykalne'?”. Fillozofia Oświecenia. Radykalizm - religia - kosmopolityzm. (Eds.) Miklaszewska, Justyna. Tomaszewska, Anna. Transl. Tomaszewska, Anna. Kraków: Wydawnictwo Uniwersytetu Jagiellońskiego, 2015. 46-65.

Malia, Martin. Sowiecka tragedia. Historia komunistycznego imperium rosyjskiego 19171991. Transl. Hułas, Magdalena. Wyzner, Elżbieta. Warszawa: Philip Wilson, 1998.

Plechanow, Jerzy. Historia rosyjskiej myśli społecznej. Wybór. T. I. Transl. Hekkier, Regina et al. Warszawa: Książka i Wiedza, 1966.

Russkaya mysl'v vek Prosveshcheniya. (Eds.) Utkina, Nina Fiodorovna. Suchov, Andrey Dmitryevich. Moskva: Nauka 1991 [Русская мысль в век Просвещения. (Ред.) Уткина, Нина Федоровна. Сухов, Андрей Дмитриевич. Москва: Наука, 1991].

Walicki, Andrzej.Zarys myśli rosyjskiej. Od Oświecenia do renesansu religijno-filozoficznego. Kraków: Wydawnictwo Uniwersytetu Jagiellońskiego, 2005.

Zenkovskiy, Vasiliy Vasilievich. Istoriya russkoy filosofii. T. I. Ch. 1. Leningrad: Ego, 1991 [Зеньковский, Василий Васильевич. История русской философии. Т. І. Ч. 1. Ленинград: Эго, 1991]. 